\title{
Nature and the Supernatural in the Medieval and Early Modern Imagination
}

\author{
Laura Chuhan Campbell ${ }^{1}$
}

Accepted: 25 August 2021 / Published online: 24 October 2021

(c) The Author(s), under exclusive licence to Springer Nature B.V. 2021

The three articles in this dossier examine temporally and geographically diverse instances of interactions between human beings and the natural world in medieval and Early Modern Europe. Whether these interactions are literary, political, or scientific, the supernatural plays an important role in mediating the ability of human beings to control, alter, or assimilate with their environment.

Magic intervenes in human interactions with the natural world in Todd Andrew Borlik's article, which draws on a variety of sources-ranging from literary and scientific texts, protest ballads, and medical remedies-to examine the debate over the draining of the fens in Early Modern England. While the inhospitable wetlands were characterised as a home for witches and demons, the fen-dwellers themselves turned accusations of witchcraft back upon the engineers who used technology to dominate the landscape. Exploring the quasi-magical implications of John Dee's "hydragogie" alongside Ben Jonson's satirical take on the "diabolical" projectors, Borlik reflects on the way in which magic and demonology were invoked to debate the ideological implications of radical ecological interventions.

The ability of nature to evoke the superhuman and the supernatural is further explored in Christine Ferlampin-Acher's article, which examines the motif of the animal nurse in late medieval French literature. While feeding infants with animal milk was an attested practice in the European Middle Ages, literary motifs that show abandoned children being fed and/or raised by animals were used to symbolically mark the hero as special. As Ferlampin-Acher argues, intertextual play between hagiography, romance, and epic imbues the figure of the animal parent with religious and/or totemic value, through which the intimate contact of human- animal breastfeeding gives the child a strength and power deriving from animality. It emerges, however, as a motif specifically associated with the epic genre, deploying a particular conception of nature as a generic marker even at a time when boundaries between genres were becoming more fluid.

Laura Chuhan Campbell

1.j.campbell@dur.ac.uk

1 School of Modern Languages and Cultures, Durham University, Elvet Riverside, New Elvet, Durham DH13JT, United Kingdom 
Similarly in Timothy Bourns' article, which turns our attention to human-animal transformations in medieval Icelandic literature, magic plays a role in blurring the boundaries between humans and animals. Bourns' analysis demonstrates that human-animal transformations in these texts destabilise multiple binary oppositions that are collocated to the dichotomy of humans and animals, examining cases of humanised animals and animalised humans that undercut a strict dichotomy between the two. As in the case of the animal foster-parents studied by Ferlampin-Acher, animal power is magically transferred to humans by direct and intimate contact (in this case, eating flesh or wearing skin), but the transfer is not linear or unidirectional. Instead, this boundary-crossing activity represents a state of oscillation between categories, which reveals a complex understanding of human-animal entanglement in the medieval Icelandic imagination.

These studies, then, mark out liminal spaces between human beings and their environments, where magic mediates relationships of domination, transformation, or nurturing. More broadly, they examine the role of narrative, literary genre, and contemporary politics in shaping these imagined boundaries and carving out space for the supernatural. Magic, in these texts, offers a way of imagining non-human voices and perspectives, as well as decoupling human concerns and agency from the human body.

I would like to acknowledge the work of Megan Cavell in the earlier stages of compiling and editing this dossier, and offer my thanks for her contributions.

Publisher's Note Springer Nature remains neutral with regard to jurisdictional claims in published maps and institutional affiliations. 